\title{
PENINGKATAN KETERAMPILAN DISKUSI SISWA KELAS VII SMP NEGERI 5 TEBING TINGGI MELALUI MODEL PEMBELAJARAN TWO STAY TWO STRAY
}

\author{
Erika Sitorus \\ Surel: erikasitorus21@gmail.com
}

\begin{abstract}
ABSTRAK
Penelitian ini bertujuan untuk meningkatkan proses pembelajaran diskusi dan meningkatkan keterampilan diskusi siswa kelas VII SMP N 5 Tebing Tinggi, melalui model pembelajaran Two Stay Two Stray. Hasil penelitian yang diperoleh yaitu persentase ketercapaian indikator keterampilan diskusi mengalami peningkatan pada setiap siklus. Hasil penelitian menunjukkan: (1) secara proses, pembelajaran diskusi mengalami peningkatan yang signifikan. Sebelum implementasi tindakan, siswa masih belum aktif melakukan diskusi dan belum mampu bekerjasama dengan baik pada saat berdiskusi. Setelah implementasi tindakan, siswa menjadi aktif dan mampu bekerjasama dengan baik pada saat berdiskusi; (2) secara produk, siswa dalam berdiskusi pada saat pratindakan dengan skor rata-rata 7,31 dan pada akhir pelaksanaan tindakan yakni siklus III menjadi 20,90. Kemampuan siswa dalam berdiskusi mengalami peningkatan sebesar 13,59.
\end{abstract}

Kata Kunci : Two Stay Two Stray, Keterampilan Diskusi

\section{PENDAHULUAN}

Pada

pembelajaran

keterampilan berbicara, terdapat berbagai kegiatan, antara lain: bercerita berdasar gambar, berbicara berdasar rangsang suara, wawancara, diskusi, pidato, dan debat. Pembelajaran diskusi merupakan salah satu keterampilan berbicara yang diajarkan di sekolah. Dalam silabus sekolah, pembelajaran diskusi memiliki standar kompetensi dan kompetensi dasar: mengungkapkan pikiran, perasaan, dan informasi melalui kegiatan berkenalan, berdiskusi, dan bercerita. pembelajaran tersebut adalah mendiskusikan masalah (yang ditemukan dari berbagai berita, artikel, atau buku). Diskusi merupakan kegiatan memecahkan sebuah permasalahan secara bersama-sama untuk mengambil kesimpulan dari permasalahan tersebut. Melalui diskusi, siswa berlatih untuk berkomunikasi dengan orang lain secara berkelompok. Siswa juga dituntut untuk aktif mengeluarkan ide/gagasan untuk memberikan pendapat tentang suatu permasalahan melalui kegiatan berdiskusi. Hal ini mampu merangsang kreativitas, keberanian, membangun kerjasama kelompok, dan melatih sikap saat berkomunikasi dengan orang lain.

Pada pelaksanaan pembelajaran diskusi, seringkali siswa kurang mampu melakukan diskusi dengan tepat. Siswa hanya sekedar berdiskusi untuk melaksanakan tugas dalam mata 

pelajaran bahasa Indonesia tanpa memperhatikan tujuan dan manfaat dari pembelajaran tersebut. Banyak siswa mengalami kesulitan ketika harus mengungkapkan pikiran atau pendapatnya di hadapan teman sekelasnya. Siswa lebih banyak diam dan cenderung tidak aktif. Terlebih pada praktiknya, siswa sulit dalam menyampaikan gagasannya tentang sebuah permasalahan dalam sebuah forum. Oleh karena itu, siswa membutuhkan pemahaman mengenai apa itu diskusi dan bagaimana cara melakukan diskusi yang baik, khususnya berdiskusi dalam sebuah kelompok.

Dari permasalahan di atas, diperlukan model pembelajaran yang tepat untuk meningkatkan keterampilan diskusi siswa. Dalam menentukan model pembelajaran diperlukan pemahaman yang mendalam mengenai materi yang akan disampaikan dan pengetahuan tentang model pembelajaran yang sesuai. Model pembelajaran yang sudah ada sangat banyak sehingga harus dipilih model yang sesuai dengan tujuan pembelajaran. Situasi dan kondisi siswa di kelas juga harus diperhatikan sehingga pada prosesnya tidak mengalami hambatan yang justru akan merugikan siswa. Oleh karena itu, seorang guru dituntut untuk dapat memilih dan menerapkan model pembelajaran di kelas agar materi pembelajaran dapat tersampaikan dengan optimal. Di samping itu, guru harus mampu menyesuaikan model pembelajaran dengan kondisi siswa di kelas selama proses pembelajaran sehingga dapat meningkatkan keterampilan berbicara siswa khususnya dalam pembelajaran diskusi.

Berdasar hasil observasi awal dan wawancara peneliti dengan rekan guru Bahasa Indonesia kelas VII SMP N 5 Tebing Tinggi, secara umum ditemukan beberapa kendala yang dihadapi pada saat pelaksanaan pembelajaran diskusi di kelas, seperti: siswa kurang mengetahui tentang diskusi yang baik, siswa cenderung pasif dan sulit untuk berbicara, siswa kurang berani dan kurang aktif dalam mengutarakan gagasan atau pikirannya pada saat kegiatan berdiskusi. Pembelajaran diskusi di kelas VII SMP N 5 Tebing Tinggi, belum menggunakan model pembelajaran yang sesuai, sehingga pada pelaksanaannya belum berhasil secara optimal. Hal inilah yang menjadi permasalahan dalam pembelajaran diskusi. Oleh karena itu, peneliti mencoba menerapkan model pembelajaran Two Stay Two Stray dalam pembelajaran diskusi.

Two Stay Two Stray merupakan model pembelajaran kooperatif yang memberi kesempatan kepada kelompok untuk membagikan hasil dan informasi dengan kelompok lain. Banyak kegiatan belajar mengajar yang diwarnai dengan kegiatan-kegiatan individu, padahal pada kenyataan hidup di luar sekolah, manusia itu saling membutuhkan satu dengan yang lainnya (Lie, 2010: 62). Pada pembelajaran dengan model ini siswa 
Erika Sitorus : Peningkatan Keterampilan Diskusi ...

diajarkan untuk secara aktif melakukan diskusi secara berkelompok dan bekerjasama membahas sebuah permasalahan.

$$
\text { Kelebihan }
$$
model pembelajaran Two Stay Two Stray ini dalam diskusi yakni siswa dapat aktif selama pembelajaran dan lebih menguasai permasalahan yang didiskusikan. Pelaksanaannya dilakukan dengan membentuk kelompok yang masing-masing anggota terdiri dari empat siswa dengan kemampuan yang heterogen. Siswa akan merasa memiliki tanggung jawab dan ketertarikan untuk melaksanakan kegiatan ini. Siswa juga lebih berwawasan luas, mempunyai ide, dan aktif mengungkapkan pikiran dan gagasan mereka. Dengan model pembelajaran ini, siswa akan mampu berbicara karena langkah dalam model Two Stay Two Stray mengharuskan siswa untuk berbicara dalam sebuah diskusi. Pembelajaran diskusi menggunakan model Two Stay Two Stray diharapkan mampu menciptakan suasana pembelajaran yang aktif dan menarik serta menyenangkan bagi siswa. Selain itu, guru juga dapat lebih mudah dalam membimbing siswa. Penerapan model ini diharapkan dapat menjadi alternatif bagi guru dalam pembelajaran diskusi agar semakin meningkat. Oleh karena itu, perlu dilakukan penelitian mengenai penerapan model pembelajaran Two Stay Two Stray pada mata pelajaran Bahasa Indonesia dalam rangka membantu meningkatkan kemampuan diskusi siswa kelas VII SMP N 5 Tebing Tinggi.

Tujuan penelitian ini adalah untuk meningkatkan proses pembelajaran diskusi dan meningkatkan keterampilan diskusi siswa kelas VII SMP N 5 Tebing Tinggi, melalui model pembelajaran Two Stay Two Stray.

\section{METODE PENELITIAN}

Berdasarkan kerangka teori dan kerangka pikir yang telah diuraikan di atas, hipotesis tindakan ini adalah model pembelajaran Two Stay Two Stray dapat meningkatkan keterampilan diskusi siswa kelas VII SMP N 5 Tebing Tinggi.

Penelitian ini dilakukan di SMP N 5 Tebing Tinggi, yang berlokasi Jalan Letda Sujono Kecamatan Bajenis Kota Tebing Tinggi. Lokasi ini dipilih karena selain tempat peneliti mengajar juga peneliti ingin meningkatkan proses pembelajaran dan keterampilan berdiskusi siswa kelas VII SMP N 5 Tebing Tinggi.

Penelitian ini dilaksanakan mulai bulan Januari sampai Maret 2017 yang meliputi keseluruhan kegiatan mulai dari penyusunan proposal kegiatan hingga pelaksanaan penelitian. Pelaksanaan penelitian disesuaikan dengan kalender pendidikan tahun ajaran 2017 (semester II). Adapun pelaksanaanya sesuai dengan jadwal pelajaran Bahasa Indonesia.

Subjek dalam penelitian ini adalah siswa kelas VII-3 SMP N 5 Tebing Tinggi. Penentuan kelas ini 
didasarkan pada tingkat permasalahan sesuai hasil observasi dan wawancara dengan guru yang dilakukan sebelum penelitian, yakni: masih rendahnya keterampilan siswa dalam kegiatan diskusi.

Objek dalam penelitian ini adalah keterampilan diskusi siswa dalam proses pembelajaran Bahasa Indonesia melalui model pembelajaran Two Stay Two Stray.

\section{HASIL PENELITIAN DAN PEMBAHASAN}

Pada bab ini disajikan hasil penelitian yang sesuai dengan rumusan masalah yang diajukan. Hasil penelitian disajikan dengan Deskripsi secara rinci mulai dari perencanaan, pelaksanaan tindakan, pengamatan, dan refleksi. Hasil penelitian keterampilan berbicara khususnya berdiskusi siswa disajikan mulai dari tahap pratindakan sampai dengan akhir siklus. Sebelum dideskripsikan hasil penelitian dan pembahasannya, terlebih dahulu dideskripsikan keterampilan awal berdiskusi siswa sebelum dikenai tindakan, yakni pada tahap pratindakan. Berikut merupakan Deskripsi hasil kegiatan diskusi siswa pada tahap pratindakan.

\section{SIKLUS I}

Secara proses, pada siklus I ini siswa menjadi lebih berani dan aktif selama proses pembelajaran berlangsung. Siswa yang pada saat pratindakan hanya diam saja, pada siklus I mulai aktif berbicara mengungkapkan pendapatnya. Proses pembelajaran di kelas menjadi lebih hidup dan. Hal ini terlihat dari antusias siswa dalam melakukan diskusi menggunakan model pembelajaran Two Stay Two Stray. Siswa terlihat semangat bertamu ke kelompok lain dan bertanya secara aktif untuk mengetahui pendapat mengenai permasalahan dari kelompok lain. Akan tetapi, beberapa siswa terutama siswa perempuan masih malu-malu ketika bertamu ke kelompok siswa laki-laki. Sementara itu, siswa yang tinggal di tempat terlihat bersemangat membagikan informasi ke siswa yang bertamu. Implementasi model pembelajaran Two Stay Two Stray ini belum sepenuhnya berhasil. Hal ini disebabkan oleh beberapa siswa yang masih belum mengerti apa tugasnya dan prosedur pelaksanaannya.

Secara produk, peningkatan keterampilan diskusi siswa dapat dilihat dari tes diskusi. Peningkatan skor dapat dilihat dari rata-rata skor pratindakan ke siklus I yang dapat dilihat pada tiap-tiap aspeknya. Peningkatan tersebut yakni: (1) aspek keberanian/semangat pada pratindakan mendapat skor rata-rata kelas sebesar 1,54 dan meningkat pada siklus I menjadi 2,82. Peningkatan skor rata-rata kelas pada aspek ini adalah 1,28; (2) aspek kelancaran berbicara pada saat pratindakan mempunyai skor ratarata kelas sebesar 1,41 dan skor ratarata kelas pada siklus I adalah 2,41. Dari data tersebut, aspek kelancaran berbicara mengalami peningkatan sebesar 1,00; (3) aspek kejelasan 
ucapan dan pilihan kata memperoleh skor rata-rata kelas sebesar 1,41 pada saat tes pratindakan, kemudian pada tindakan siklus I mengalami peningkatan menjadi 2,50. Peningkatan pada aspek ini sebesar 1,09 ; (4) aspek penguasaan masalah memperoleh skor rata-rata kelas sebesar 1,50 pada tes pratindakan dan meningkat menjadi 2,41 pada saat siklus I. Peningkatan skor ratarata kelas yang terjadi pada aspek penguasaan masalah dari pratindakan ke siklus I adalah 0,91; dan (5) aspek pendapat (persetujuan dan sanggahan) mengalami peningkatan skor rata-rata kelas sebesar 1,00. Pada saat pratindakan diperoleh skor rata-rata kelas sebesar 1,45 dan mengalami peningkatan pada siklus I menjadi 2,45.

Dari hasil yang terdapat pada siklus I baik secara proses maupun produk menunjukkan bahwa terdapat peningkatan yang cukup, namun masih kurang maksimal karena masih terdapat beberapa kendala yang dihadapi. Dari hasil tersebut, semua aspek penilaian produk masih tergolong dalam kategori cukup sehingga masih perlu ditingkatkan lagi pada pelaksanaan siklus berikutnya, khususnya pada aspekaspek berikut:

a. Siswa masih kurang paham terhadap prosedur model pembelajaran Two Stay Two Stray.

b. Siswa masih kurang pada aspek kelancaran berbicara.

c. Siswa masih kurang dalam aspek penguasaan masalah d. Siswa masih kurang maksimal pada aspek penyampaian pendapat (persetujuan dan sanggahan).

Hasil refleksi baik secara proses maupun produk beserta kendala permasalahannya pada pelaksanaan siklus I akan menjadi dasar pelaksanaan siklus berikutnya yakni siklus II.

\section{SIKLUS II}

Secara proses, pada siklus II ini siswa sudah terlihat aktif selama proses pembelajaran berlangsung. Siswa yang pada saat siklus I kurang aktif berbicaraberdiskusi, pada siklus II sudah aktif berdiskusi mengungkapkan pendapatnya. Sikap siswa saat di kelas sudah tenang dan terkondisi dengan baik. Proses pembelajaran di kelas terlihat lebih hidup. Hal ini terlihat dari antusias siswa dalam melakukan diskusi menggunakan model pembelajaran Two Stay Two Stray. Siswa terlihat semangat bertamu ke kelompok lain dan bertanya secara aktif untuk mengetahui pendapat mengenai permasalahan dari kelompok lain. Beberapa siswa terutama siswa perempuan yang pada saat siklus I masih tampak malu-malu ketika bertamu ke kelompok siswa laki-laki, pada tindakan siklus II sudah terlihat berani. Sementara itu, siswa yang tinggal di tempat tampak bersemangat membagikan informasi ke siswa yang bertamu. Namun, pada saat proses diskusi berlangsung, 
siswa masih kurang memotivasi anggota lain dalam kelompoknya.

Secara produk, peningkatan keterampilan diskusi siswa dapat dilihat dari tes diskusi. Peningkatan skor dapat dilihat dari rata-rata skor siklus I ke siklus II yang dapat dilihat pada tiap-tiap aspeknya. Peningkatan tersebut yakni: (1) aspek keberanian/semangat pada siklus I mendapat skor rata-rata kelas sebesar 2,82 dan meningkat pada siklus II menjadi 3,72. Peningkatan skor ratarata kelas pada aspek ini adalah 0,90 ; (2) aspek kelancaran berbicara pada saat siklus I memperoleh skor ratarata kelas sebesar 2,41 dan skor ratarata kelas pada siklus II adalah 3,36. Dari data tersebut, aspek kelancaran berbicara mengalami peningkatan sebesar 0,95; (3) aspek kejelasan ucapan dan pilihan kata memperoleh skor rata-rata kelas sebesar 2,50 pada saat siklus I, kemudian pada tindakan siklus II mengalami peningkatan menjadi 3,31. Peningkatan pada aspek ini sebesar 0,81 ; (4) aspek penguasaan masalah memperoleh skor rata-rata kelas sebesar 2,41 pada siklus I dan meningkat menjadi 3,31 pada saat siklus II. Peningkatan skor rata-rata kelas yang terjadi pada aspek penguasaan masalah dari siklus I ke siklus II adalah 0,90; dan (5) aspek penyampaian pendapat (persetujuan dan sanggahan) mengalami peningkatan skor rata-rata kelas sebesar 0,96. Pada saat siklus I diperoleh skor rata-rata kelas sebesar 2,45 dan mengalami peningkatan pada siklus II menjadi 3,41. Dari hasil yang terdapat pada siklus II baik secara proses maupun produk menunjukkan bahwa terdapat peningkatan yang baik, namun masih kurang maksimal karena masih terdapat beberapa kendala yang dihadapi. Permasalahan tersebut kemudian dibahas dengan kolabolator untuk dicari solusi pada siklus berikutnya. Adapun kendalakendala tersebut sebagai berikut.

a. Siswa belum maksimal pada aspek kejelasan ucapan dan pilihan kata

b. Siswa masih kurang dalam penguasaan topik diskusi

c. Siswa kurang maksimal pada aspek kelancaran berbicara.

Berdasar hasil refleksi baik secara proses maupun produk beserta kendala permasalahannya pada pelaksanaan siklus II, masih terdapat beberapa aspek yang belum maksimal, sehingga pelaksanaan tindakan dilanjutkan ke siklus III agar dicapai hasil yang lebih maksimal

\section{SIKLUS III}

Secara proses, pada siklus III ini siswa sudah aktif selama proses pembelajaran berlangsung. Pada siklus III ini siswa sudah bekerja sama dengan baik dalam kelompok selama berdiskusi. Siswa mampu mengorganisasikan kelompok, membuat inisiatif kerja kelompok selama proses pembelajaran berlangsung. Proses pembelajaran di kelas terlihat lebih hidup. Hal ini terlihat dari antusias siswa dalam 
melakukan diskusi menggunakan model pembelajaran Two Stay Two Stray. Siswa terlihat bersemangat bertamu ke kelompok lain dan bertanya secara aktif untuk mengetahui pendapat mengenai permasalahan dari kelompok lain. Sementara itu, siswa yang tinggal di tempat dengan semangat membagikan informasi ke siswa yang bertamu. Pada saat proses diskusi berlangsung, siswa sudah mampu memotivasi anggota lain dalam kelompoknya.Secara produk, peningkatan keterampilan diskusi siswa dapat dilihat dari tes diskusi. Peningkatan skor dapat dilihat dari rata-rata skor siklus II ke siklus IIIyang dapat dilihat pada tiap-tiap aspeknya. Peningkatan tersebut yakni: (1) aspek keberanian/ semangat pada siklus II mendapat skor rata-rata kelas sebesar 3,72 dan meningkat pada siklus III menjadi 4,36. Peningkatan skor rata-rata kelas pada aspek ini adalah 0,64; (2) aspek kelancaran berbicara pada saat siklus II memperoleh skor rata-rata kelas sebesar 3,36 dan skor rata-rata kelas pada siklus IIIadalah 4,13. Dari data tersebut, aspek kelancaran berbicara mengalami peningkatan sebesar 0,77 ;

(3) aspek kejelasan ucapan dan pilihan kata memperoleh skor ratarata kelas sebesar 3,31 pada saat siklus II, kemudian pada tindakan siklus III mengalami peningkatan menjadi 4,04. Peningkatan pada aspek ini sebesar 0,73 ; (4) aspek penguasaan masalah memperoleh skor rata-rata kelas sebesar 3,31 pada siklus II dan meningkat menjadi 4,13 pada saat siklus III. Peningkatan skor rata-rata kelas yang terjadi pada aspek penguasaan masalah dari siklus II ke siklus III adalah 0,82; dan (5) aspek penyampaian pendapat (persetujuan dan sanggahan) mengalami peningkatan skor ratarata kelas sebesar 0,81. Pada saat siklus II diperoleh skor rata-rata kelas sebesar 3,41 dan mengalami peningkatan pada siklus III menjadi 4,22 .

Secara keseluruhan, seluruh aspek penilaian keterampilan diskusi pada siklus III sudah meningkat lebih baik dibandingkan dengan tahap pratindakan. Pada siklus III ini telah mencapai target yang telah ditentukan, keberhasilannya yakni $75 \%$ dari jumlah siswa yang hadir memperoleh skor $\geq 19$.

\section{SIMPULAN}

Berdasarkan hasil penelitian dan pembahasan yang telah dikemukakan pada bab sebelumnya, maka dapat disimpulkan bahwa pembelajaran diskusi dengan model pembelajaran Two Stay Two Stray dapat meningkatkan keterampilan diskusi siswa kelas VII-3 SMP N 5 Tebing Tinggi.

Peningkatan keterampilan diskusi siswa tampak pada kualitas proses pembelajaran yang ditunjukkan dengan kekompakan siswa yang sudah baik. Siswa yang pada saat pratindakan kurang mampu bekerjasama, pada siklus III sudah kompak satu sama lain di dalam kelompoknya. Siswa sudah mampu memotivasi anggota lain, yakni 
dengan mengingatkan akan tugasnya. Pengorganisasian kelompok pada siklus III sudah baik bila dibandingkan dengan pratindakan. Inisiatif kerja kelompok siswa pada saat pratindakan belum begitu tampak, namun pada siklus III sudah baik. Siswa sudah mampu menentukan apa yang harus dilakukan pada saat diskusi. Peningkatan yang paling menonjol ialah keaktifan siswa. Jika pada saat pratindakan siswa terlihat pasif dan diam, pada saat siklus III siswa sudah aktif melakukan diskusi. Dengan adanya siswa yang bertamu, menjadikan suasana pembelajaran lebih hidup dan antusias.

Peningkatan hasil/produk

dapat diketahui dari kemampuan berdiskusi siswa sebelum dikenai tindakan dan sesudah dikenai tindakan. Pada saat tes pratindakan, skor siswa masih tergolong kurang. Siswa masih terlihat diam, malu, dan kurang aktif melakukan diskusi. Siswa kurang berani menyampaikan ide/argumen dan kurang lancar dalam berbicara. Setelah dikenai tindakan (siklus III), kemampuan siswa mengalami peningkatan yang baik. Peningkatan keterampilan diskusi siswa dapat dilihat dari 5 aspek, yaitu (1) aspek keberanian/semangat, (2) aspek kelancaran berbicara, (3) aspek kejelasan ucapan dan pilihan kata, (4) aspek penguasaan masalah, dan (5) aspek penyampaian pendapat (persetujuan dan sanggahan). Peningkatan secara produk berdasarkan jumlah skor rata-rata kelas yang diperoleh yakni pada tes pratindakan sebesar 7,31 atau $29,63 \%$, pada siklus I meningkat menjadi 12,59 atau $50,54 \%$, pada siklus II meningkat menjadi 17,09 atau $68,36 \%$, dan pada akhir tindakan siklus III meningkat menjadi 20,90 atau $83,63 \%$.

\section{DAFTAR RUJUKAN}

Anwar, K. and Ananda, L. J. 2017. Pembuatan "Science Logbook" Melalui Scientific Approach Sebagai Upaya Meningkatkan Keterampilan Menulis Mahasiswa Pgsd. School Education Journal PGSD FIP UNIMED, 6(2), pp.12-20.

Arikunto, Suharsimi. 2006. Prosedur Penelitian Suatu Pendekatan Praktik. Jakarta: Rineka Cipta.

Arsjad, G. Maidar dan Mukti U.S. 2005. Pembinaan Kemampuan Berbicara Bahasa Indonesia. Jakarta: Erlangga.

Alwi, Hasan, dkk. 2002. Kamus Besar Bahasa Indonesia. Jakarta: Balai Pustaka.

Bulatau, S. J. 2003. Teknik Diskusi Kelompok. Yogyakarta: Kanisius.

Dipodjojo, Asdi S. 1984. Komunikasi Lisan. Yogyakarta: Penerbit Lukman.

Mailani, E. 2014. Upaya Meningkatkan Kompetensi Paedagogik Guru Dalam Menyusun Rencana Pelaksanaan Pembelajaran Melalui Kegiatan Pendampingan (Mentoring). 
Erika Sitorus : Peningkatan Keterampilan Diskusi ...

School Education Journal

PGSD FIP UNIMED, 1(2).

Goldberg, Alvin A dan Carl E.

Larson. 1985. Komunikasi

Kelompok Proses-proses

Diskusi dan Penerapannya.

Jakarta: Universitas Indonesia

Press.

Hendrikus, Dori Wuwur. 2009.

Retorika Terampil Berpidato,

Berdiskusi, Berargumentasi,

Bernegosiasi. Yogyakarta:

Kanisius.

Iskandarwassid, dkk. 2008. Strategi

Pembelajaran

Bahasa.

Bandung: Rosda.

Lie, Anita. 2010. Cooperative

Learning Mempraktikkan

Cooperative Learning di

Ruang-ruang Kelas. Jakarta:

Grasindo.

Madya, Suwarsih. 2006. Teori dan Praktik Penelitian Tindakan. Bandung: Alfabeta.

Nurgiyantoro, Burhan. 2010.

Penilaian Pembelajaran

Bahasa. Yogyakarta: BPFE.

Sugiyanto. 2009. Model-Model

Pembelajaran Inovatif.

Surakarta: Panitia Sertifikasi

Guru Rayon 13 FKIP UNS

Surakarta. 